\title{
Water hyacinth second-generation ethanol production: a mitigation alternative for an environmental problem
}

Giovana Roberta Francisco Bronzato, Sábrina Martina Ziegler, Rita de Cássia da Silva, Ivana Cesarino \& Alcides Lopes Leão

To cite this article: Giovana Roberta Francisco Bronzato, Sábrina Martina Ziegler, Rita de Cássia da Silva, Ivana Cesarino \& Alcides Lopes Leão (2018): Water hyacinth second-generation ethanol production: a mitigation alternative for an environmental problem, Journal of Natural Fibers, DOI: $\underline{10.1080 / 15440478.2018 .1458000}$

To link to this article: https://doi.org/10.1080/15440478.2018.1458000

Published online: 02 Apr 2018.

Submit your article to this journal ऍ

Щ Article views: 54

View Crossmark data $\longleftarrow$ 


\title{
Water hyacinth second-generation ethanol production: a mitigation alternative for an environmental problem
}

\author{
Giovana Roberta Francisco Bronzato ${ }^{a}$, Sábrina Martina Ziegler ${ }^{b}$, Rita de Cássia da Silva \\ Ivana Cesarino ${ }^{a}$, and Alcides Lopes Leão ${ }^{a}$
}

aSchool of Agriculture, São Paulo State University (UNESP), Botucatu, Brazil; 'bebensmittelwissenschaft und Biotechnologie, Universitaet Hohenheim, Stuttgart, Deutschland

\begin{abstract}
Natural fibers are very abundant, especially those derived from water plant as water hyacinth. The water hyacinth, which is rich in cellulosic fiber content, has a great ability to adapt itself to harsh conditions and at very high growth rate. Therefore, it is considered a pest due to environmental and economical damage to water bodies. A proposed alternative to mitigate the excessing water hyacinth problem is to use its biomass aiming the production of second-generation ethanol $(2 \mathrm{G})$, using cellulose as feedstock. It was been implemented different methods to optimize the production of 2G from water hyacinth. Two approaches were considered: a separate chemical pretreatment process and two-way processes to enzymatic hydrolysis using separated hydrolysis and fermentation (SHF) or simultaneous saccharification and fermentation (SSF). The chromatography analysis showed that the hydrogen peroxide hydrolysis is the more effective pretreatment and that SSF has the highest productivity. The ethanol output can minimize the water hyacinth removal cost through some economical and environmental return.
\end{abstract}

\begin{abstract}
摘要
天然纤维非常丰富, 尤其是从水植物中提取的水葫芦。水葫芦富含纤维 素纤维, 具有很强的适应恶劣环境和高生长速率的能力。因此, 由于环 境和经济对水体的破坏, 它被认为是有害生物。一个建议的替代方案以 减轻过高的水葫芦问题是利用其生物量为第二代乙醇生产，以纤维素为 原料。采用不同的方法优化水葫芦生产第二代乙醇。被认为是两个途 径: 一个单独的化学预处理和酶解分离的双向过程的水解和发酵 (SHF) 或同步糖化发酵（SSF）。色谱分析表明, 过氧化氢水解是更有效的预处 理和SSF具有最高的生产率。乙醇产量可以通过一定的经济效益和环境效 益将水葫芦去除成本降至最低。
\end{abstract}

\section{KEYWORDS}

Water hyacinth; second-generation ethanol; chemical hydrolysis; enzymatic hydrolysis; alcoholic fermentation; biofuel

关键词

水葫芦; 第二代乙醇; 化学 水解; 酶法水解; 酒精发酵; 生物燃料

\section{Introduction}

Water hyacinth, Eichornia crassipes, is an aquatic macrophyte native from Brazil that represents a problem because of its high growth rate, its ability to compete with other aquatic plants, and its ease of propagation. These characteristics lead to a massive amount of biomass that can cover a large part of a water body, which affects navigation, water flow, hydropower generation, and are responsible for drastic changes in aquatic fauna and flora by reducing the levels of oxygen in the water. Therefore, water hyacinth can be considered as an aquatic pest that has spread out around the world, especially in tropical areas (Téllez et al. 2008). This plant has more water in its constitution

CONTACT Alcides Lopes Leão $\otimes$ alcidesleao@fca.unesp.br $@$ School of Agriculture, São Paulo State University (UNESP), Rua Jose Barbosa de Barros, 1780, CEP 18610307, Botucatu, FCA/UNESP, Brazil.

Color versions of one or more of the figures in the article can be found online at www.tandfonline.com/wjnf. 
than dry matter, reaching more than $90 \%$ of moisture content. The biochemical characterization of the biomass showed values of $10 \%$ lignin, $25 \%$ cellulose, $35 \%$ hemicellulose, and $25 \%$ ash. The amount of ash is high because of the property of this plant to remove and accumulate substances from water bodies such as heavy metals (Ganguly, Chatterjee, and Dey 2012; Gao et al. 2016; Rezania et al. 2015). The water hyacinth fibers have already been evaluated for several applications as polyester composites (Abral et al. 2014), geotextiles (Methacanona et al. 2010) and natural fiberreinforced plastic composites (Taj, Munawar, and Khan 2007; Tumolva, Ortenero, and Kubouchi 2013).

The global demand for fossil fuel increases each year; consequently, other important alternative sources with a low amount of pollution have been considered that the normal oil derived. In Brazil, distillation of fermented sugarcane juice produces ethanol, which is considered an environmentfriendly fuel, also called a renewable fuel or biofuel (Petrobras 2002). Ethanol can also be produced from corn starch, which is the most usual option in the world, mainly due to the US production, about 15 million gallons in 2015, most from corn. Although, starch made from other grains can also be used. This process is employed by the US and other countries such as China, Canada, France, Germany, and Sweden (Lennartsson, Erlandsson, and Taherzadeh 2014). Another method for producing ethanol is through the enzymatic process, in which a degradation of cellulose into glucose occurs. The resulting biofuel is called second-generation ethanol (2G).

Meanwhile, there are different types of lignocellulosic material used for $2 \mathrm{G}$ ethanol production such as colza (canola), corn or wheat stover, pine chips, and elephant grass. However, the process is still limited by economic challenges, particularly the costs of enzymes, which are used in the production of biofuel (Cotana et al. 2014; Lennartsson, Erlandsson, and Taherzadeh 2014; LópezLinares et al. 2014; Santos et al. 2012). The production of lignocellulosic ethanol can be divided into five simple steps: biomass grinding; biomass chemical pretreatment; enzymatic hydrolysis; fermentation of sugarcane juice; and distillation of fermented sugarcane juice. The challenge is to determine the best pretreatment - including efficiency and costs - since each raw material has different percentages of lignin, cellulose, and hemicellulose, and there is also variation in the composition of pentosans, which also influences the yield (Oliveira 2012).

Several methods can be used as pretreatment depending on the biomass and its proportions of the lignin-cellulose-hemicellulose complex. They can be classified as physical, chemical, biological, or a combination among them (Santos et al. 2012). The pretreatment is a step used aiming to expose the lignocellulosic material for enzyme attack. Also, brings other benefits such as prevents the cellulose and hemicellulose destruction by strong acids, avoids the formation of possible inhibitors of hydrolytic enzymes and fermenting microorganisms; minimizes energy expenditure; decreases the cost of raw materials for a scale down process; produces little waste; and the consumption of some chemicals. Moreover, if a chemical is necessary, it must be derived from a cheap product as well preferentially be renewable (Taherzadeh and Karimi 2008).

Enzymatic hydrolysis is a biochemical process that degrades the cellulose in the pretreatment step into glucose, which will be fermented by yeast. This process performed by the cellulase, an enzymatic complex that consists of three enzymes acting synergistically; the product of one enzyme is the substrate of the other (Ogeda and Petri 2010).

The glucose, hydrolyzed by enzymes of the cellulase, is the substrate used in fermentation. This process can be done using two different possibilities: separated hydrolysis and fermentation (SHF) or simultaneous saccharification and fermentation (SSF). In SHF, both processes are done in sequence, and enzymatic hydrolysis is followed by alcoholic fermentation in a separate vessel. The main advantage of this process is that both steps achieve their optimal conditions (Castro and Pereira 2010). In SSF, enzymatic hydrolysis and fermentation take place in the same bioreactor. This method reduces the problem of cellulase inhibition caused for sugars, which can inhibit the enzyme. The sugars are consumed before accumulating in the bioreactor. The parameters of this process are intermediate between the optimal parameters of the enzyme and yeast. In comparison with SHF, the simultaneous process has the following advantages: increasing 
of the enzymatic hydrolysis rate; less enzyme use; increasing of yield; less need for sterile conditions; less process time; and the use of only one bioreactor. However, the ethanol itself may cause cellulase inhibition (Sun and Cheng 2002).

Water hyacinth represents a potential raw material for the $2 \mathrm{G}$ technology, because of the cellulose present in its structure. This process transforms a pest in a commercial product, which reduces the problem it causes to the environment. However, as the use of this plant in $2 \mathrm{G}$ ethanol production is recent is necessary to find the best pretreatment and the most adequate process for enzymatic hydrolysis and fermentation.

This paper studies the $2 \mathrm{G}$ ethanol production from water hyacinth with the objective of decrease the environment and economics problems caused by excess of this plant in the rivers. It was considered different chemical processes of pretreatment (acid hydrolysis, autohydrolysis, and peroxide hydrolysis), and two methods of enzymatic hydrolysis and alcoholic fermentation (simultaneous and separated).

\section{Material and methods}

\section{Material}

Water hyacinth was collected manually from the riverside of the Tietê River in São Manuel, State of São Paulo, Brazil. The whole plant was washed and cut into small pieces. These pieces were then dried in an oven at $60^{\circ} \mathrm{C}$ for approximately $50 \mathrm{~h}$. After this process, the dry samples were ground in a Willey knives mill and the particles used in the chemical pretreatment was a size lower than 42 mesh $(0.355 \mathrm{~mm})$.

Commercial enzyme by Novozymes, called Cellic CTec3, was used for enzymatic hydrolysis. The yeast Saccharomyces cerevisiae, by Fleischmann, with the commercial name Dry and Instantaneous Biologic Yeast, was used for fermentation. For pretreatment process, it was used the following analytical grade reagents: acetic acid, citric acid, sodium hydroxide, hydrogen peroxide, and acetone. Also deionized water was used during all investigation processes and solutions preparation.

\section{Methods}

\section{Biomass pretreatment}

After the grinding process, the pretreatments (autohydrolysis, acid hydrolysis, and peroxide hydrolysis) were performed in the water hyacinth. In all pretreatments, the parameters used were the same in all processes: solution concentration (except for autohydrolysis), sample quantity, solution volume, and pressure and time inside the autoclave. Therefore, it was performed all tree biomass pretreatments with steam explosion, in a vertical autoclave, and with a pressure of $2.5 \mathrm{kgf} / \mathrm{cm}^{2}$ per h. In each process, it was varied only the solvent: water (autohydrolysis), hydrogen peroxide (peroxide hydrolysis), and acetic acid (acid hydrolysis). In all processes using chemical reagents, we used a $1.7 \mathrm{~mol} \mathrm{~L}^{-1}$ concentration of all solvents and prepared them with deionized water. Each pretreatment used $30.0 \mathrm{~g}$ of water hyacinth, and $2.0 \mathrm{~L}$ of solution.

After the chemical hydrolysis with steam explosion, all pretreated biomass went through the same procedures. Firstly, the solution was filtered, the liquid was discarded, and the solid was put in a $20 \mathrm{v} / \mathrm{v}$ solution of acetone/water. After 15 minutes, the solution was filtered again and the biomass was washed with deionized water. The biomass was then put in small quantities into an ultrasonic cell disruptor. Finally, the pretreated biomass was dried in a compartment drier at $50^{\circ} \mathrm{C}$ until it reached a humidity level lower than $5 \%$.

\section{Enzymatic hydrolysis and alcoholic fermentation}

It was measured the moisture content and calculated the quantity of dry matter of each pretreated biomass. For ethanol production, it was used $250 \mathrm{~mL}$ erlenmeyer flasks as bioreactors. In each flask, approximately, $5.0 \mathrm{~g}$ of biomass was weighted, equivalent to $5.0 \mathrm{~g}$ of dry matter. In total was 
prepared, 72 bioreactors, 24 with each pretreatment: water, hydrogen peroxide and acetic acid. In each bioreactor, it was added $200 \mathrm{~mL}$ of deionized water after weighing the water hyacinth. The erlenmeyer flasks were covered with cotton plugs and autoclaved for 15 minutes at $121^{\circ} \mathrm{C}$.

SSF. In this process, enzymatic hydrolysis and alcoholic fermentation take place in the same bioreactor at the same time. The experiment was performed in duplicates, totalizing 12 bioreactors (erlenmeyer flasks) for each pretreatment. The $\mathrm{pH}$ of all erlenmeyer flasks was buffered in 4.8 with citric acid/sodium hydroxide. We then added, to each bioreactor, $1.5 \mathrm{~mL}$ of cellulase and $20 \mathrm{~mL}$ of inoculum (approximately 10\% of the volume of the recipient). This inoculum was previously prepared with $5^{\circ}$ Brix autoclaved sugarcane juice inoculated with $5.0 \mathrm{~g}$ of commercial yeast (Saccharomyces cerevisiae) during $24 \mathrm{~h}$. The 12 bioreactors were put inside an incubator with controlled temperature and rotation of $32^{\circ} \mathrm{C}$ and $120-\mathrm{rpm}$, respectively. The bioreactors remained in the incubator for different times $(0,6,12,24,48$ and $72 \mathrm{~h})$.

After these processes, the Erlenmeyer flasks were put in a $90^{\circ} \mathrm{C}$ water bath to deactivate the enzymes and kill the yeast. Finally, the hydrolyzed/fermented solutions were filtered in a vacuum pump, and the resulting liquid was stored to be analyzed.

SHF. Twelve erlenmeyer flasks were replaced in the same way as in item 2.2.2.1., two for each pretreatment, with $\mathrm{pH}$ 5. After being autoclaved, it was added $1.5 \mathrm{~mL}$ of cellulase enzyme and the flasks were put in the incubator with a controlled temperature of $50^{\circ} \mathrm{C}$ and $120 \mathrm{rpm}$ rotation. After $72 \mathrm{~h}$, all flasks were put in a 15 minute water bath at $90^{\circ} \mathrm{C}$ to deactivate the enzyme. After, the $\mathrm{pH}$ was then buffered at 4.8 and the bioreactors were autoclaved. Following, $20 \mathrm{~mL}$ of the Saccharomyces cerevisiae innocuous substance were added. The bioreactors were put one more time in the incubator at a $32^{\circ} \mathrm{C}$ temperature and $120 \mathrm{rpm}$ rotation. The erlenmeyer flasks returned in the incubator for different times $(0,6,12,24,48$, and $72 \mathrm{~h})$, plus the $72 \mathrm{~h}$ from enzymatic hydrolysis, totalizing therefore $72,78,84,96,120$, and $144 \mathrm{~h}$, respectively. After that, the flasks were put in a water bath to kill the yeasts. Finally, it was filtered each experiment in a vacuum pump and the liquid was stored to be analyzed. Figure 1 shows a flowchart of the methodology used in the production of $2 \mathrm{G}$ ethanol.

\section{Gas chromatography analysis}

The filtered liquids from processes 2.2.2.1. and 2.2.2.2. were analyzed by gas chromatography, in CG Thermo equipment, Trace 1310 model with capillary column TR-1 - $30 \mathrm{~m}$ length with $0.25 \mathrm{~mm}$ internal diameter and $0.25 \mathrm{um}$ film thickness (stationary phase) and the detector FID (flame ionization detector) in $200^{\circ} \mathrm{C}$.

Standards used in concentrations of $0.050 \% ; 0.200 \%$ and $0.400 \%$ with a result $\mathrm{R} 2=0.9926$. The inside standard used was n-propanol P.A. (Vetec) and the outside standard was etanol P.A. (Vetec). The autosampler was used like "headspace" brand Teledyne Tekmar, model Versa.

\section{Results and discussion}

The obtained results were evaluated in order to find the best process, between the purpose procedures of this work, to produce $2 \mathrm{G}$ ethanol from water hyacinth biomass.

Figure 2 shows the results of each pretreatment, separated by hydrolysis and fermentation types (SHF or SSF). The pretreatment with hydrogen peroxide presented the best yield in both processes. This shows that this reagent was more effective in causing changes in the lignin-hemicellulosecellulose complex, which makes it easier for enzymes to access cellulose, and providing a higher quantity of substrate (glucose) to yeasts.

Considering the observed results, it was calculated the process yield based on the quantity of biomass dry matter that was used. The optimization was made considering the time of the enzymatic hydrolysis and alcoholic fermentation step, referent of the better yield. For the SHF the time is bigger than for the SSF. All these data are showed in Table 1, in which can be seen that the hydrogen 


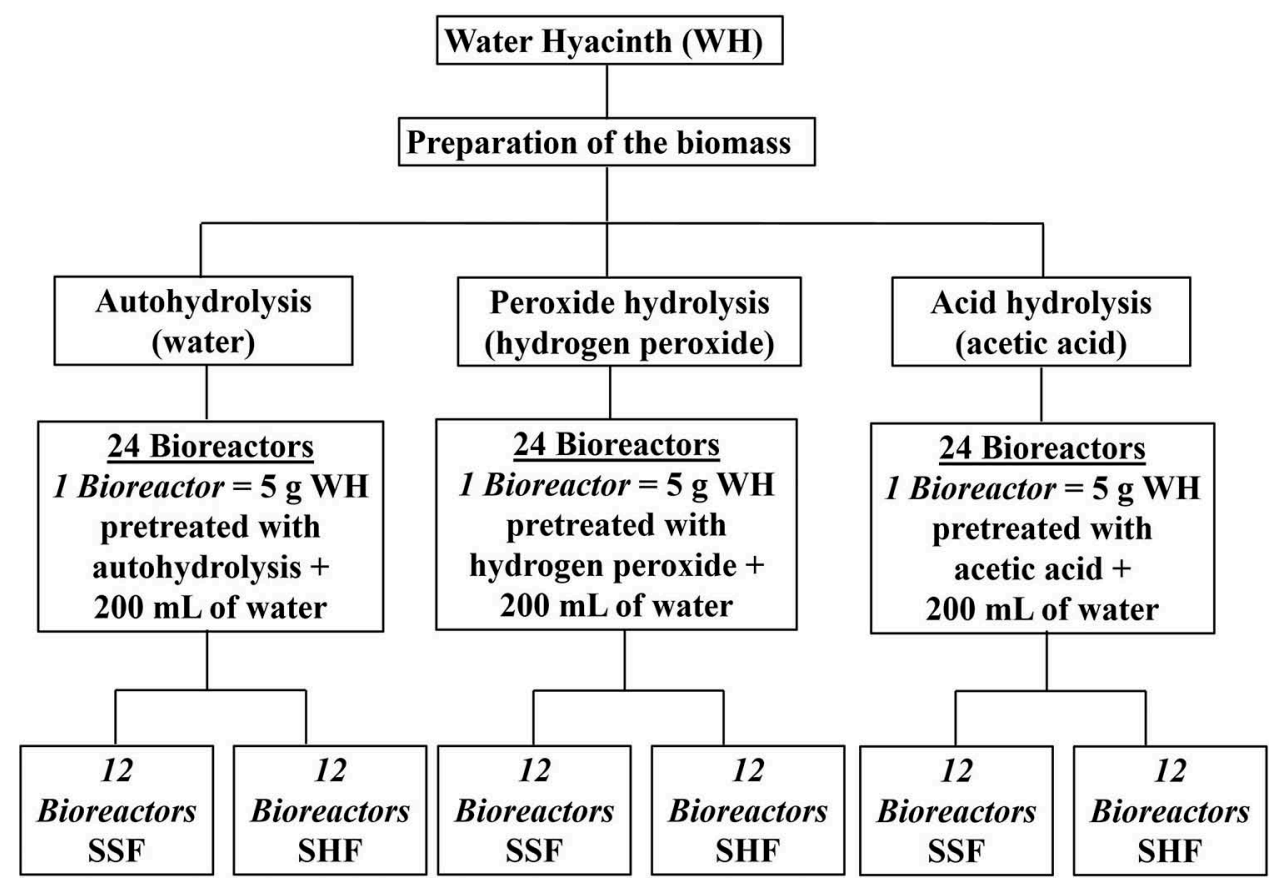

Figure 1. Flowchart of the methodology used in the production of $2 \mathrm{G}$ ethanol.

peroxide has the highest yield and that all pretreatments have a better yield in SFF. This happens because the productivity is proportionally inverse by the time. When the process time decreases its productivity increases.

Satyanagalakshmi et al. (2011) and Das et al. (2016) used Eichhornia crassipes as raw material by 2G ethanol production; however, both did the biomass pretreatment with sulfuric acid and did not study the SHF process. Table 2 compare the found results in this work with the others two researches.

Table 2 shows that the obtained yield, in this work, is better than Satyanagalakshmi et al. (2011) results, however, is smaller than results found per Das et al. (2016), that used two microorganisms for fermentation, $S$ cerevisiae, a yeast normally utilized in alcohol fermentation, and Z. mobilis, one bacteria with more fast fermentation and that show the ethanol yield biggest than with yeast (Ernandes and Garcia-Cruz 2009).

The industrial process measures the yield of ethanol production in liter of ethanol/tons of biomass (L/t). In Table 1 the yield is calculated in $\mathrm{mL}$ of ethanol/grams of dry biomass $(\mathrm{mL} / \mathrm{g}$ ). Therefore, two modifications are necessary. The first one are the units and the second is the dry water hyacinth for natural water hyacinth that has only 3\% of dry material. For the calculation was utilized the result of best productivity process that is the pretreatment with hydrogen peroxide followed to SSF process.

Ethanol/dry water hyacinth: $0.042 \mathrm{~mL} / \mathrm{g} \rightarrow 42 \mathrm{~L} / \mathrm{t}$.

Ethanol/natural water hyacinth: $0.0013 \mathrm{~mL} / \mathrm{g} \rightarrow 1.3 \mathrm{~L} / \mathrm{t}$.

In 1 hectare grows $220 \mathrm{~kg}$ of water hyacinth per day, therefore in 1 year there are 80 ton of $E$. crassipes (Bayrakci and Koçar 2014; Das et al. 2016). Although these figures can varies depending climate, water conditions, etc., with this rate is possible to produce in 1 year, $100 \mathrm{~L}$ of ethanol per each hectare of water hyacinth in hydric bodies. Of course cannot be compared to the sugar cane, which produces, in average in Brazil, 7,000 L/ha/yr, showing that this process is more environmental than economical. This production followed the concept "Eradication through utilization," and it is interesting for decrease the problems caused by excess of water hyacinth in rivers. 

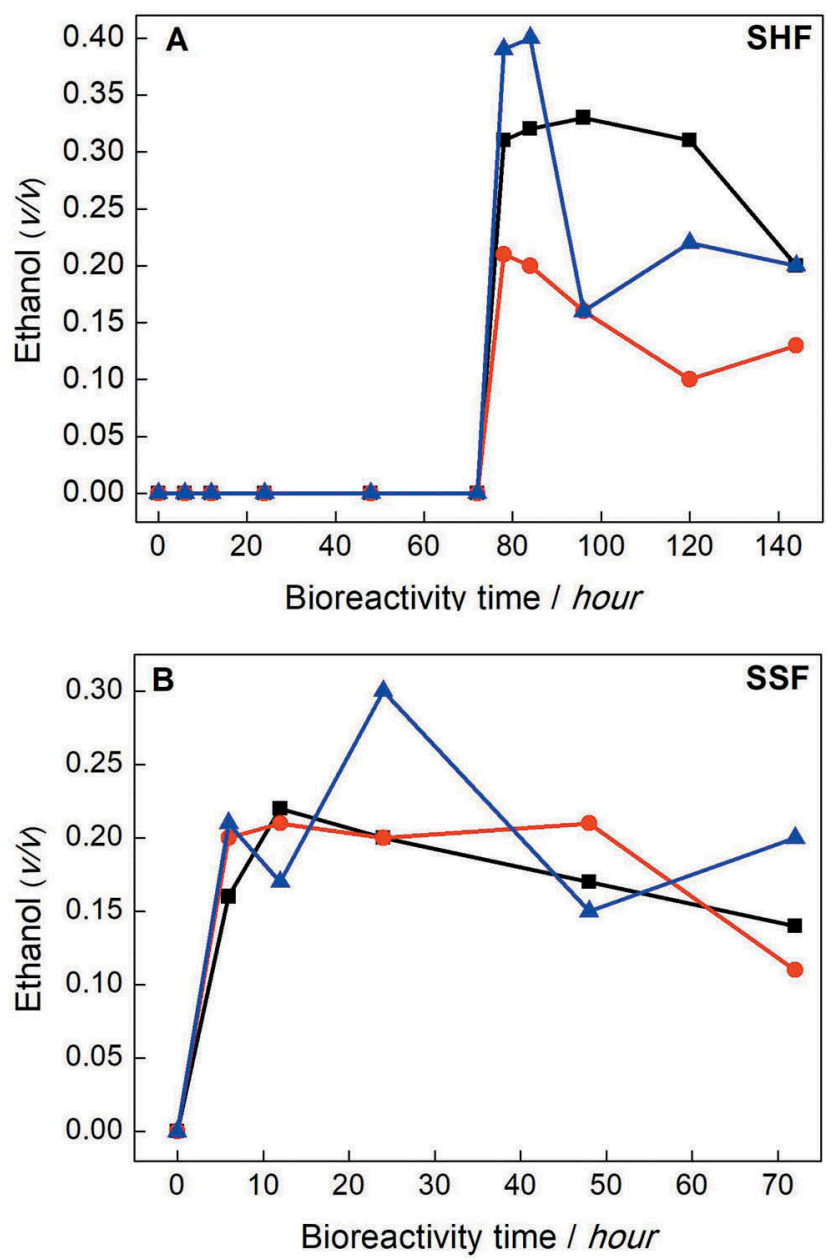

Figure 2. Production of $2 \mathrm{G}$ ethanol from water hyacinth using (A) separated hydrolysis and fermentation and (B) simultaneous saccharification and fermentation to different pretreatment: $(\boldsymbol{\Lambda})$ hydrogen peroxide, $(\mathbf{\square})$ acetic acid and $(\bullet)$ water.

Table 1. Yield of pretreatment on SHF and SSF processes.

\begin{tabular}{llccccc}
\hline Process & Pretreatment & Time $(\mathrm{h})$ & Ethanol $(\mathrm{mL})$ & Water hyacinth $(\mathrm{g})$ & Yield $(\mathrm{mL} / \mathrm{g})$ & Productivity $(\mathrm{mL} / \mathrm{g} \mathrm{h})$ \\
\hline SHF & Acetic acid & 96 & 0.33 & 5 & 0.066 & 0.001 \\
& Hydrogen peroxide & 78 & 0.39 & & 0.078 & 0.001 \\
& Water & 78 & 0.21 & & 0.042 & 0.001 \\
SSF & 12 & 0.22 & 5 & 0.044 & 0.004 \\
& Acetic acid & 6 & 0.21 & & 0.042 & 0.007 \\
& Hydrogen peroxide & 12 & 0.21 & & 0.042 & 0.004 \\
\hline
\end{tabular}

Table 2. Comparison of the obtained results with other works.

\begin{tabular}{lccc}
\hline Studies & Acid & $\begin{array}{c}\text { Yield } \\
(\mathrm{mg} \text { ethanol/mL solution) }\end{array}$ & Main differences \\
\hline This work & Acetic $(10 \% \mathrm{v} / \mathrm{v})$ & 4.0 & - \\
Satyanagalakshmi et al. $2011^{15}$ & Sulfuric $(2 \% \mathrm{v} / \mathrm{v})$ & 3.0 & Hydrolysis: Cellulase -Zytec enzymatic complex \\
Das et al. $2016^{16}$ & Sulfuric $(2 \% \mathrm{v} / \mathrm{v})$ & 14.0 & Fermentation: S. cerevisiae Z. mobilis \\
\hline
\end{tabular}




\section{Conclusion}

In this investigation, it has been implemented different methodologies to produce $2 \mathrm{G}$ ethanol using water hyacinth as raw material. The study shows that the most efficient reagent is the hydrogen peroxide, for this pretreatment showed the best yield of ethanol production. The data show that this reagent can better solubilize hemicellulose and lignin in comparison with other methods, which results in a higher enzymatic hydrolysis, for the enzyme can easily access the cellulose. Therefore, the most effective methodology to produce $2 \mathrm{G}$ ethanol from water hyacinth is the pretreatment with hydrogen peroxide followed by SSF. Thereby, the study proved that is possible to reduce the excess of water hyacinth in bodies of water by $2 \mathrm{G}$ ethanol production.

\section{Acknowledgments}

The authors would like to acknowledge the financial support of FAPESP (2015/21395-9), CNPq, CAPES, and Mr. Fábio Iachel da Silva for the CG analysis.

\section{Funding}

This work was supported by the Fundação de Amparo à Pesquisa do Estado de São Paulo [2015/21395-9];

\section{References}

Abral, H., D. Kadriadi, A. Rodianus, P. Mastariyanto, Ilhamdi, S. Arief, S. M. Sapuan, and M. R. Ishak. 2014. Mechanical properties of water hyacinth fibers - Polyester composites before and after immersion in water. Materials and Design 58:125-29.

Bayrakci, A. G., and G. Koçar. 2014. Second-generation bioethanol production from water hyacinth and duckweed in Izmir: A case study. Renewable \& Sustainable Energy Reviews 30:306-16.

Castro, A. M., and N. Pereira Jr. 2010. Produção, propriedades e aplicação de celulases na hidrólise de resíduos agroindustriais. Química Nova 33:181-88.

Cotana, F., G. Cavalaglio, M. G. A. Nicolini, V. Coccia, and A. Petrozzi. 2014. Production of bioethanol in a second generation prototype from pine wood chips. Energy Procedia 45:42-41.

Das, A., P. Ghosh, T. Paul, U. Ghosh, B. R. Pati, and K. C. Mondal. 2016. Production of bioethanol as useful biofuel through the bioconversion of water hyacinth (Eichhornia crassipes). 3 Biotech 6:70.

Ernandes, F. M. P. G., and C. H. Garcia-Cruz. 2009. Zymomonas Mobilis: Um microrganismo promissor para a fermentação alcoólica. Semina:CienciasAgrárias 30:361-80.

Ganguly, A., P. K. Chatterjee, and A. Dey. 2012. Studies on ethanol production from water hyacinth-A review. Renewable Sustainable Energy Reviews 16:966-72.

Gao, Y., B. Yu, K. Wu, Q. Yuan, X. Wang, and H. Chen. 2016. Physicochemical, pyrolytic,and combustion characteristics of hydrochar obtained by hydrothermal carbonization of biomass. Bioresources 11:4113-33.

Lennartsson, P. R., P. Erlandsson, and M. J. Taherzadeh. 2014. Integration of the first and second generation bioethanol processes and the importance of by-products. Bioresources Technology 165:3-8.

López-Linares, J. C., I. Romero, C. Cara, E. Ruiz, E. Castro, and M. Moya. 2014. Experimental study on ethanol production from hydrothermal pretreated rapeseed straw by simultaneous saccharification and fermentation. Journal of Chemical Technology and Biotechnology 89:104-10.

Methacanona, P., U. Weerawatsophona, N. Sumransina, C. Prahsarna, and D. T. Bergado. 2010. Properties and potential application of the selected natural fibers as limited life geotextiles. Carbohydrate Polymers 82:1090-96.

Ogeda, T. L., and D. F. S. Petri. 2010. Hidrólise enzimática de biomassa. Química Nova 33:1549-58.

Oliveira, M. 2012. Entre açúcares e genes. Revista Fapesp 200:86-91.

Petrobras. 2002. Curso de formação de operadores de refinaria - Processo de refino. Curitiba, Brazil: Abadie, E.

Rezania, S., M. Ponraj, M. F. M. Din, A. R. Songip, F. M. Sairan, and S. Chelliapan. 2015. The diverse applications of water hyacinth with main focus on sustainable energy and production for new era: An overview. Renewable and Sustainable Energy Reviews 41:943-54.

Santos, F. A., J. H. De Queiróz, J. L. Colodette, S. A. Fernandes, V. M. Guimarães, and S. T. Rezende. 2012. Potencial da palha de cana-de-açúcar para produção de etanol. Química Nova 35:1004-10.

Satyanagalakshmi, K., R. Sindhu, P. Binod, K. U. Janu, R. K. Sukumaran, and A. Pandey. 2011. Bioethanol production from acid pretreated water hyacinth by separate hydrolysis and fermentation. Journal of Scientific \& Industrial Research 70:156-61. 
Sun, Y., and J. Cheng. 2002. Hydrolysis of lignocellulosic materials for ethanol production: A review. Bioresources Technology 83:1-11.

Taherzadeh, M. J., and K. Karimi. 2008. Pretreatment of lignocellulosic wastes to improve ethanol and biogas production: A review. International Journal of Molecular Sciences 9:1621-51.

Taj, S., M. A. Munawar, and S. Khan. 2007. Natural fiber-reinforced polymer composites. Proceeding Pakistan Academic Science 44:129-44.

Téllez, T. R., E. M. R. López, G. L. Granado, E. A. Pérez, R. M. López, and J. M. S. Guzmán. 2008. The water hyacinth, eichhornia crassipes: An invasive plant in the guadiana river basin (Spain). Aquatic Invasions 3:42-53.

Tumolva, T., J. Ortenero, and M. Kubouchi. 2013. Characterization and treatment of water hyacinth fibers for NFRP composites. The 19th International Conference on Composite Materials, 1-11. 28 July-2 August, Montreal, Canada. 